\author{
УДК 32-027.21 \\ https://doi.org/10.34142/24130060.2020.20.1.05
}

\title{
ТНК ЯК СУБ’ЄКТИ ЗОВНІШНЬОЇ ПОЛІТИКИ ДЕРЖАВ
}

\author{
С. Є. Свсєєв, І. В. Тодріна
}

Харківський національний університет будівництва і архітектури

Глобальна економіка сприяє створенню нових ичентрів розподілу ресурсів $i$ влади в світовому масштабі. Повноиінними суб'єктами міжнародної політики стали транснаціональні корпорації (ТНК).

Феномен ТНК доиільно розглядати в рамках двох підходів:

- $\quad$ як інструмент проведення зовнішньої політики розвинених країн у відношенні краӥн, щуо розвиваються;

- $\quad$ в якості самостійного актора, здатного своїми діями впливати на зовнішню і внутрішню політику не лише крайн, щзо розвиваються, але й індустріально розвинених країн.

Незалежно від того, наскільки саме самостійним актором є ТНК, вона так чи інакше впливає на зовнішню політику країни походження та країни базування.

Ключові слова: транснаціональні корпорації, міжнародна політика.

\section{ТНК КАК СУБЪЕКТЫ ВНЕШНЕЙ ПОЛИТИКИ ГОСУДАРСТВ}

\section{С. Е. Евсеев, И. В. Тодрина}

Глобальная экономика способствует созданию новых иентров распределения ресурсов и власти в мировом масштабе. Полноценными субъектами международной политики стали транснациональные корпораџии (ТНК).

Феномен ТНК целесообразно рассматривать в рамках двух подходов:

- $\quad$ как инструмент проведения внешней политики развитых стран в отношении развивающихся стран;

- $\quad$ в качестве самостоятельного актора, способно своими действиями влиять на внешнюю и внутреннюю политику не только развивающихся, но и индустриально развитых стран.

Независимо от того, насколько самостоятельном актором является ТНК, она так или иначе влияет на внешнюю политику страны происхождения и странь базирования.

Ключевые слова: транснациональные корпорачии, международная политика.

\section{TNC AS SUBJECTS OF FOREIGN POLICY OF STATES}

\section{S. Evseev, I. Todrina}

The global economy is fostering the creation of new centers for the distribution of resources and power on a global scale. Transnational corporations (hereinafter - TNCs) became full-fledged subjects of international politics. The activities of TNCs undermine the sovereignty of the nation-state, but at the same time plays an important role in the integration of the world 
economy and political relations. At the same time, both main corporate models (American and European) are focused on close interaction with the financial system and state organization.

Both the United States and the leading countries of the European Union use TNCs to effectively realize their national interests outside their territory. But, on the other hand, these interests are generated by the state under the strong influence of transnational corporations, which use the potential of states - both the United States and regional leaders - to support their interests in the world market with the help of power tools.

The phenomenon of TNCs should be considered in two approaches:

- $\quad$ as a tool for conducting foreign policy of developed countries in relation to developing countries;

- $\quad$ as an independent actor, with his actions he is able to influence the foreign and domestic policy of not only developing, but also industrialized countries.

Regardless of how independent the multinational corporation is, it somehow affects the foreign policy of the country of origin and country of residence. The tool of TNCs' influence on the state mechanism is the control over the centers of political and state decision-making and their personnel through investments in the economy, lobbying and direct bribery. The interests of the corporation are intertwined with the state to such an extent that they acquire the status of national interests. In this regard, the foreign policy of the national state becomes a reflection of the goals and objectives of not only this state, but also TNCs.

Key words: transnational corporations, international politics.

Постановка проблеми. В даний час активно досліджується проблема впливу недержавних акторів на розвиток світової політики. Вивчення ролі і місця транснаціональних корпорацій (у подальшому зовнішньополітичних стратегіях держав пов’язана 3 питанням про вплив трансформацій, які зазнає система міжнародних відносин, на зовнішню політику суверенних країн. Так, деякі вчені вважають, що в умовах глобалізації жодна держава вже не може вести традиційну зовнішню політику, а сучасні інтеграційні процеси сприяють тому, що ТНК стають новими повноцінними суб'єктами зовнішньої політики (Voronianskyi, 2012b; Denysenko, 2015b). При цьому особлива увага приділяється вивченню сутності та характеру участі ТНК в геополітичних процесах.

Аналіз актуальних досліджень. Окремі випадки впливу ТНК на внутрішню і зовнішню політику окремих держав стали предметом багатьох міждисциплінарних досліджень на Заході. Зокрема, Р. Гілпін (1975) описав американські ТНК як інструмент поширення гегемонії США. У 2000 p Дж. Грір спільно 3 директором центру 3 вивчення громадської думки 
К. Сінгхом опублікував статтю «Коротка історія транснаціональних корпорацій», два розділи якої були присвячені опису впливу ТНК на політику національних держав і ролі ТНК у світовій політиці (Greer and Singh, 2000). Авторам вдалося на основі конкретних прикладів описати використання корпораціями військово-політичних ресурсів розвинених країн у спробі вплинути на внутрішню i зовнішню політику країн, що розвиваються. Однак в українській політичній науці через домінуючу в ній апологетику дискурсу «західної демократії» феномен впливу ТНК на державну політику залишається поза увагою більшості дослідників.

Метою даної статті $є$ розгляд сутності феномену ТНК на міжнародній арені та основних форм впливу ТНК на політику окремих держав.

Виклад основного матеріалу. Найчастіше під ТНК мають на увазі «приватні, державні або змішані підприємства, що мають відділення в двох або більше країнах, незалежно від юридичної форми і сфери діяльності цих відділень, які функціонують відповідно певної системи прийняття рішень, що дозволяє проводити узгоджену політику і загальну стратегію через один або кілька центрів прийняття рішень» (Samusenko, 2014). За останні два десятиліття число ТНК в світі збільшилося 311 до 82 тис., а число їх філій зі 104 до 807 тис. На глобальні виробничі системи ТНК припадає 80\% світової торгівлі (Organizaciya Obedinennyh Nacij, 2013). Обсяг виробництва багатьох ТНК можна порівняти за величиною з ВВП великих держав. В єдиному світовому списку національних економік і ТНК контрольний пакет акцій належить корпораціям (51 позиція з 100 найбільших економік світу) (Giuliani and Macchi, 2014). Активи закордонних філій ТНК складають 21 трлн. доларів США, а число зайнятих - 46 млн. чоловік. Обсяг продажів закордонних філій становить 16 трлн. доларів. За різними оцінками на ТНК припадає від 65 до 75\% світового експорту (Organizaciya Obedinennyh Nacij, 2013).

Діяльність транснаціональних компаній підриває національний суверенітет, але одночасно відіграє важливу роль в інтеграції світової 
економіки i політичних відносин. ТНК планують i організовують виробництво в глобальному масштабі і одночасно пристосовуються до місцевих потреб і умов. Глобалізація дозволяє ТНК уникати державного регулювання і контролю з боку державних інститутів. Найбільші корпорації розглядають неоліберальну глобалізацію як перспективу створення нових центрів влади, які формують правила розподілу ресурсів і влади в світовому масштабі (Voronianskyi, 2012a).

Детальне ознайомлення 3 особливостями організації корпорацій економічно розвинених країн дозволяє виділити дві основні моделі: англоамериканську та німецьку або континентально-європейську. Основна відмінна риса англо-американської моделі полягає в тому, що формальне право впливати на прийняття стратегічних рішень і політику корпорації мають тільки їі акціонери. Менеджери і наймані працівники в корпорацію не входять (Giuliani and Macchi, 2014 ). Однак, оскільки менеджери виступають як агенти акціонерів, їм делегуються права щодо оперативного управління корпорацією. Разом 3 характерною для американської моделі високою роздробленістю пакетів акцій корпорації (у більшості великих компаній кількість акціонерів обчислюється сотнями тисяч і мільйонами, а найбільші пакети акцій - одиницями відсотків) це також означає, що жоден з акціонерів не має можливості контролювати дії топ-менеджменту, на користь якого зміщується реальна влада всередині корпорації.

В Європі домінує німецька модель, для якої характерне включення в корпорацію не лише акціонерів, але й організованих у профспілки працівників підприємств, що працюють на корпорацію, а також фінансових структур, що надають корпорації додатковий капітал, головним чином у вигляді кредитів. Виняткова роль банків визначається особливостями німецького законодавства, згідно 3 яким приватні інвестори не мають доступу на фондові біржі, а купують i продають акції за допомогою посередників, в основному - банків (Giuliani and Macchi, 2014). У наглядових радах та правліннях німецьких корпорацій домінують представники банків, а 
також державні чиновники, оскільки держава, як правило, володіє значними пакетами акцій всіх великих фірм. Таким чином, обидві моделі корпорації орієнтовані на тісну взаємодію 3 фінансовою системою та державною організацією (в якій представникам фінансових кіл належить особлива роль).

Як США, так і країни-лідери Свропейського союзу використовують ТНК для ефективної реалізації своїх національних інтересів за межами своєї території. Але, з іншого боку, самі ці інтереси генеруються державою під сильним впливом ТНК, які використовують весь потенціал держав - як США, так і регіональних лідерів - для підтримки своїх інтересів на світовому ринку за допомогою владних інструментів. ТНК, володіючи можливістю контролю над банківською сферою, податковою політикою і економікою держав - регіональних лідерів, здатні вплинути на динаміку розвитку не тільки світової економіки, а й світової політики, тим самим обмежуючи суверенітет національних держав (Voronianskyi, 2012b).

Доцільно розглядати корпорацію в рамках двох різних підходів: як інструмент проведення зовнішньої політики розвинених країн (найбільш поширений) і в якості самостійного актора, здатного своїми діями впливати на зовнішню і внутрішню політику не лише країн, що розвиваються, але й індустріально розвинених країн.

Розглядаючи корпорації через призму першого підходу, слід зазначити, що прямі іноземні інвестиції, що здійснюються через ТНК, і розширення діяльності самих корпорацій можна вважати основним інструментом збільшення економічного і як наслідок - політичного впливу розвинених країн на країни, що розвиваються (Denisenko, 2013). Отримуючи прямі іноземні інвестиції, держава часто стає економічно залежною i втрачає можливість проходження вектору самостійного політичного розвитку. Також збільшення частки іноземної присутності в економіці національної держави сприяє формуванню відповідно орієнтованої еліти. Така еліта впливає на прийняття внутрішньо- і зовнішньополітичних рішень (Denysenko, 2015a). 3 
цього випливає, що ТНК здатні впливати як на державну систему в цілому, так і на окремих осіб, які приймають державні рішення.

Особливий приклад використання ТНК в ролі засобу проведення зовнішньої політики ілюструє активність транснаціонального бізнесу в Каспійському регіоні. Саме політичний, а не економічний підтекст яскраво виражений в державних інвестиціях США в енергетичний сектор Казахстану i Туркменістану, основною метою яких було позбавити Росію статусу транспортного монополіста на Каспії (Gilpin, 1975). Також прикладом подібного впливу може послужити політика Китаю в Африці. В одній тільки Замбії в ролі інвесторів виступили близько 180 китайських ТНК (Samusenko, 2014).

Слід зазначити, що, переслідуючи певну мету в країнах, що розвиваються, ТНК можуть вплинути також і на зовнішню політику розвинених країн. Так, саме по собі залучення розвинених країн для впливу на політику країн, що розвиваються, передбачає, що ТНК впливають на зовнішню політику цих розвинених держав. Це і є сутністю другого підходу до вивчення ТНК як самостійних суб'єктів формування державної політики. Наприклад, на актуальну політику КНР наразі активно впливають не лише місцеві корпорації, що вже набули характеру транснаціональних, але й діючі в Китаї «класичні» західні ТНК: Volkswagen, Boing, Microsoft, McDonald's, General Electric, Royal-Dutch / Shell, Coca-Cola, IBM General Motors, Nestle, Ford, Philips, Mobile Oil, Ace Braun Bovary, Siemens, British Petroleum, Unilever і т.д.

Яскравим прикладом впливу інтересів ТНК на зовнішньополітичну стратегію США є бойові дії в Іраку та Лівії Як відомо, один із головних лобістів вторгнення в ці держави Д. Чейні до призначення на посаду віцепрезидента США займав пост голови ради директорів компанії Halliburton, яка після подій в Іраку отримала ряд вигідних контрактів в даному регіоні.

Лобіювання ТНК відбувається і в міжнародно-правової системі. Угода про єдиний європейський ринок, договір про північноамериканську 
організацію вільної торгівлі і генеральну угоду про тарифи й торгівлю були прийняті для максимізації вигоди глобального бізнесу, ослаблення державного контролю над світовою економікою і «стирання» національних кордонів. Тут мова йде вже не про вплив на зовнішню політику будь-якої однієї країни, але про вплив на сукупність зовнішніх політик держав, на світову політику в цілому. Як приклад такого впливу відзначається прямий зв'язок між результатами діяльності недержавної комерційної структури Goldman \& Sachs і появою на міжнародній арені міждержавного об’єднання БРІКС (Samusenko, 2014; Greer and Singh, 2000).

У цілому в розвинених країнах інтереси корпорації переплітаються 3 державними до такої міри, що по суті є національними інтересами (головне питання тут полягає в тому, кому більше вигідний подібного роду синтез). У зв’язку з цим будь-яка зовнішня політика держави є відображенням цілей і завдань не тільки цієї держави, але і корпорацій. ТНК реалізують власну зовнішню політику, виражаючи їі через зовнішню політику держави походження.

На нашу думку, до інструментів впливу ТНК на зовнішню політику держави необхідно віднести:

1. Перехід державних чиновників в штат корпорації.

2. Зворотний перехід представників вищого менеджменту ТНК на державну службу і подальше лобіювання ними інтересів корпорації на рівні державного апарату.

3. Системна участь представників ТНК у ключових радах, комітетах та інших дорадчо-консультативних органах, що визначають економічну політику держави.

4. Фінансова підтримка політичних партій і еліт.

5. Лобізм, активізація груп впливу.

6. Контроль обсягів приватних інвестицій у національну економіку, можливість їх збільшення або скорочення.

7. Підкуп чиновників і осіб, що приймають державно-владні рішення. 
8. Залучення розвинених держав до захисту інтересів ТНК.

Крім того, навіть за умови, що корпорація не переслідує ніяких національних інтересів, вона служить цілям певної фінансово-політичної еліти. Так, традиційно вибори в США є боротьбою за політичний вплив нафтових ТНК, які спонсорують кампанії республіканців, і фінансових ТНК, що підтримують демократичну партію. При цьому не лише певне угруповання може використовувати різні корпорації для своїх цілей, але й одна й та ж ТНК може стати інструментом у руках конкуруючих між собою бізнес-груп. Звідси підхід до визначення ТНК як інструментів реалізації інтересів бізнес-угруповань, у тому числі й політичних (Voronianskyi, 2014; 2019), представляється абсолютно вірним. Тісний взаємозв'язок між механізмами ТНК і держави при тому, що первинними суб’єктами прийняття рішень у них є бізнес-угруповання, не дозволяє розглядати ТНК як абсолютно незалежного актора політики. Тенденція до набуття корпорацією повної незалежності може реалізуватися за умови відповідності ТНК наступними критеріями: втрата зв’язку з державою походження; здійснення діяльності виключно в інтересах бенефіціарів, відсутність будь-якого цілеспрямованого переслідування національних інтересів будь-якої держави; багатонаціональний склад управлінських кадрів; істотна для світової економіки частка виробленої продукції; розосередження філій, активів і виробничих потужностей по всьому світу.

Тому, доцільним в рамках другого підходу $є$ виділення як окремої категорії глобальних корпорацій. Глобальна корпорація відрізняється від ТНК тим, що остання «пристосовує продукти для кожного окремого ринку», а глобальна сприймає світову економіку як єдиний ринок (Giuliani and Macchi, 2014). Дане поняття було запропоновано ще в 1970-ті pp., але не прижилося в академічній спільноті. Передчасним для академічної спільноти стало також введення Г. Перлмуттером концепту «геоцентричної організації», яка відрізняється від ТНК відсутністю будь-якого політичного зв’язку 3 державою походження або базування (Perlmutter, 1969). 
Представлена відмінність глобальної корпорації від ТНК, безумовно, істотна, але не основна. Даний термін необхідно визначати, виходячи також із політичних аспектів, наділити його характеристиками про наявність сукупності засобів впливу на державу.

Висновки і перспективи подальших досліджень. ТНК виступають і в якості інструментів впливу розвинених держав на країни, що розвиваються, $\mathrm{i}$ як суб’єкти міжнародної політики. Незалежно від того, наскільки саме самостійним актором є та чи інша ТНК, вона так чи інакше впливає на зовнішню політику країни походження та країни базування. Інструментами впливу ТНК на державний механізм є, перш за все, контроль над центрами прийняття політичних та державно-владних рішень та їх персональним складом через інвестиції в економіку, лобістську діяльність і прямий підкуп. При дослідження феномену ТНК може бути доцільним виділення груп корпорацій, що набувають статусу глобальних, які контролюють світовий ринок і не прив’язані до інтересів окремої держави.

\section{ЛІТЕРАТУРА}

1. Воронянський, О. В., 2012а. Політична трансформація в контексті проблеми перерозподілу ресурсів. Вісник Харківського національного університету імені В.Н. Каразіна. Питання політології, 20(1007), c. 51-57.

2. Воронянський, О. В., 2012b. Роль національного суверенітету в легітимації державної влади. Актуальні проблеми державного управління, 2, с. 216-221.

3. Воронянський, О.В., 2014. Політичні інститути: механізм формування в конкурентному середовищі. Сучасне суспільство: політичні науки, сочіологічні науки, культурологічні науки, 1, с. 15-28.

4. Воронянський, О.В., $2019 . \quad$ Проблеми трансформації політичної суб'єктності в постіндустріальному суспільстві. Сучасне суспільство: політичні науки, соціологічні науки, культурологічні науки, 18(2), с.3747.

5. Денисенко, І. Д., 2013. Соціальні мережі в контексті соціокультурного підходу: евристичний потенціал дослідження. Вісник ХНПУ імені Г.С. Сковороди «Філософія», 40, с. 22-28.

\section{REFERENCES}

1. Voronianskyi, O. V., 2012a. Politychna transformatsiia $\mathrm{V}$ konteksti problemy pererozpodilu resursiv. Visnyk Kharkivskoho natsionalnoho universytetu imeni V.N. Karazina. Pytannia politolohii, 20(1007), s. 51-57.

2. Voronianskyi, O. V., 2012b. Rol natsionalnoho suverenitetu $\mathrm{v}$ lehitymatsii derzhavnoi vlady. Aktualni problemy derzhavnoho upravlinnia, 2, s. 216-221.

3. Voronianskyi, O. V., 2014. Politychni instytuty: mekhanizm formuvannia $\mathrm{v}$ konkurentnomu seredovyshchi. Suchasne suspilstvo: politychni nauky, sotsiolohichni nauky, kulturolohichni nauky, 1, s. 15-28.

4. Voronianskyi, O. V., 2019. Problemy transformatsii politychnoi subiektnosti $\mathrm{V}$ postindustrialnomu suspilstvi. Suchasne suspilstvo: politychni nauky, sotsiolohichni nauky, kulturolohichni nauky, 18(2), s.3747.

5. Denysenko, I. D., 2013. Sotsialni merezhi v konteksti sotsiokulturnoho pidkhodu: evrystychnyi potentsial doslidzhennia. Visnyk KhNPU imeni H.S. Skovorody 
6. Денисенко, І. Д., 2015а. Моделювання поведінки особистості в сучасних соціокультурних контекстах: методологічні засади та перспективи. Науковий вісник. "Філософія», 45 (I), с. 205-214.

7. Денисенко, І. Д., 2015b. Теорія соціального простору: евристичний потенціал щодо соціально-політичних досліджень. Сучасне суспільство: політичні науки, сочіологічні науки, культурологічні науки, 2(2), с. 27-37.

8. Организация Объединенных Наций, 2013. Доклад о мировых инвестициях. 2013. Обзор. Глобальные производственные системы: инвестиции и торговля в интересах развития. [online] ЮНКТАД. Доступно:

http://unctad.org/en/PublicationsLibrary/wir 2013overview_ru.pdf [Дата обращения 27 Октябрь 2019].

9. Самусенко, Д. Н., $\quad$ 2014. Общие и региональные особенности процессов прямого инвестирования в современном мировом хозяйстве. Фундаментальные исследования, 2-3, с. 292-295.

10. Gilpin, R., 1975. US Power and the Multinational Corporation: the Political Economy of Foreign Direct Investment. New York: Basic Books.

11. Giuliani, E. and Macchi, C., 2014. Multinational Corporations Economic and Human Rights Impacts on Developing Countries: a Review and Research Agenda. Cambridge Journal of Economics, 2, p. 479517

12. Greer, J., Singh K., 2000. A Brief History of Transnational Corporations.[online] Available at: https://www.globalpolicy.org/empire/47068a-brief-history-of-transnationalcorporations.html. [Accessed 25 October 2019]

13. Perlmutter, H. V., $1969 . \quad$ The Tortuous Eevolution of the Multinational Corporation. Columbia Journal of World Business, 4, p. 9-18.
«Filosofiia», 40, s. 22-28.

6. Denysenko, I. D., 2015a. Modeliuvannia povedinky osobystosti v suchasnykh sotsiokulturnykh kontekstakh: metodolohichni zasady ta perspektyvy. Naukovyi visnyk. «Filosofiia», 45 (I), s. 205214.

7. Denysenko, I. D., 2015b. Teoriia sotsialnoho prostoru: evrystychnyi potentsial shchodo sotsialno-politychnykh doslidzhen. Suchasne suspilstvo: politychni nauky, sotsiolohichni nauky, kulturolohichni nauky, 2(2), s. 27-37.

8. Organizaciya Obedinennyh Nacij, 2013. Doklad o mirovyh investiciyah. 2013. Obzor. Globalnye proizvodstvennye sistemy: investicii i torgovlya $v$ interesah razvitiya. [online] YuNKTAD. Dostupno: http://unctad.org/en/PublicationsLibrary/wir 2013overview_ru.pdf [Data obrasheniya 27 Oktyabr 2019].

9. Samusenko, D. N., 2014. Obshie i regionalnye osobennosti processov pryamogo investirovaniya $\mathrm{v}$ sovremennom mirovom hozyajstve. Fundamentalnye issledovaniya, 2-3, s. 292-295.

10. Gilpin, R., 1975. US Power and the Multinational Corporation: the Political Economy of Foreign Direct Investment. New York: Basic Books.

11. Giuliani, E. and Macchi, C., 2014. Multinational Corporations Economic and Human Rights Impacts on Developing Countries: a Review and Research Agenda. Cambridge Journal of Economics, 2, p. 479517

12. Greer, J. and Singh K., 2000. A Brief History of Transnational Corporations.[online] Available

at: https://www.globalpolicy.org/empire/47068a-brief-history-of-transnational-

corporations.html. [Accessed 25 October 2019]

13. Perlmutter, H. V., $1969 . \quad$ The Tortuous Eevolution of the Multinational Corporation. Columbia Journal of World Business, 4, p. 9-18.

\section{Інформація про авторів}

Свсєєв Сергій Свгенович - кандидат історичних наук, доцент, доцент кафедри економічної теорії Харківського національного університету будівництва та архітектури; e-mail: evseev.s1959@gmail.com; ORCID: http://orcid.org/0000-0002-0419-4100.

Тодріна Інна Валеріївна - кандидат економічних наук, доцент, доцент кафедри економічної теорії Харківського національного університету будівництва та архітектури; e-mail: todrina.innochka@gmail.com; ORCID: http://orcid.org/0000-0003-1381-3281. 